\title{
The Implementation Of PPI Policy Toward Service in The Public Health Center Berbek Nganjuk Regency
}

\begin{abstract}
Amin Tohari1, Byba Melda Suhita, Siti Farida

Institut Ilmu Kesehatan STRADA Indonesia

Email:

amintohari982@gmail.com

Received: October 12, 2019

Accepted : February 13, 2020

The effort to implement PPI policy have varied obstacles such as the lack of commitment and support from the stakeholder in the organization, limited financial resources to fulfill the PPI standard, limited human resources. Lack of understanding of the PPI concept and the way to implement PPI standard which is needed. The purpose of this study is to analyze The implementation of PPI policy toward service in Public Health Center Berbek Nganjuk Regency. The design of this research is to use qualitative methods using a case study approach. which is a type of qualitative research that looks closely at individual interpretations of their experiences. Data collection techniques used were Participant observational, independent interview, documentation and triangulation. Research instruments: Researchers as instruments (human instruments), notebooks, tape recorders, cameras. Data: qualitative descriptive, personal data documents, field notes, statements and actions of informants, documents etc. with a sample size of 10 informants who are officers in each service unit at the Public Health Center Berbek Nganjuk Regency.Data validation using Triangulation Technique was carried out by 2 informants. The results of this study indicate that the application of Services for patients using APD (masker, handscun, service clothes, shoes dan helmets) at the Public Health Center in Berbek Nganjuk Regency are almost all carrred out by offcers., Not all clinical service personnel carry out hand washing according to SOP in the public health center Berbek Nganjuk Regency, Not all the service places have a record of nosocomial infection at the public health certer, in Berbek, Nganjuk Regency, It was found that some of the clinical service personnel who carred out the injection were still throwing the needle closed. at the public health certer, in Berbek, Nganjuk Regency, The obstacles of PPI is the officer has less obedient with SOP that are made according to the agreement
\end{abstract}

Published : May 12, 2020
Keywords: Service, PPI, Public Health

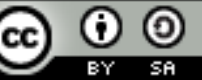

This is an open-acces article distributed under the terms of the Creative Commons Attribution-ShareAlike 4.0 International License. 


\section{INTRODUCTION}

Health development is an integral and most important part of national development, the aim of holding health development is to increase awareness, willingness and ability to live a healthy life for everyone in order to realize an optimal degree of public health. The success of health development plays an important role in improving the quality and competitiveness of Indonesia's human resources. To achieve the goals of national health development a variety of comprehensive, multi-level and integrated health efforts are held. Puskesmas are the vanguard in organizing basic health efforts (Minister of Health Regulation No. 75 of 2014 concerning Community Health Centers).

Efforts to prevent and control infections in health care facilities are very important if officials and policy makers first understand the basic concepts of infectious diseases. By and in order to realize quality health services and can become a reference for the implementation of infection prevention and control in service facilities and to create patient safety, which in turn will also have an impact on efficiency in the management of health service facilities and improving service quality (Permenkes RI Number 27 of 2017).

The implementation of the PPI program to prevent the incidence of infectious diseases related to health services or Healthcare Associated Infection (HAIs) is one of the health problems in various countries in the world, including Indonesia. In the Asian Pacific Economic Committee (APEC) or the Global Health Security Agenda (GHSA), infectious diseases related to health care have become the discussed agenda. This shows that the HAIs caused directly impact the country's economic burden (Permenkes RI No. 27 of 2017).

Infection Prevention and Control is an effort to ensure the protection of everyone against the possibility of contracting infection from public sources and while receiving health services at various health facilities. The development of science, especially in the field of health services, patient care is not only served in hospitals but also in other health care facilities, even at home (home care) (Permenkes RI Number 46 of 2015).

Implementation of infection control and prevention based on Minister of Health Regulation number 27 of 2017 must be done by all Puskesmas, this is also confirmed in the First Level Health Facility (FKTP) accreditation system as outlined in Minister of Health Decree No. 46 of 2015 which requires Puskesmas to implement Control and Prevention of infection as part of the FKTP accreditation assessment. The implementation of Infection Control (PPI) must also be carried out by the Puskesmas of Berbek in the District of Berbek in Nganjuk Regency, but the application has not yet shown the implementation that is in accordance with the expected standards. This is supported by the PPI indicator achievement data which includes services to patients using PPE (masks, hand nests, service clothes, shoes and helmets) reaching $80 \%$, services always begin with hand washing and ending with hand washing achieved $56 \%$, clinical services used were always sterile, reaching $62 \%$, clinical services using disinfectants reached $80 \%$, there were $98 \%$ liquid and solid medical waste disposal sites, there were $78 \%$ nosocomial infection logbooks, services always ensured the accuracy of the place or the area of action was $88 \%$, the aspirations were always $68 \%$ achieved, needle removal after the service was removed uncovered was $90 \%$. Data on the incidence of nosocomial infections in Berbek Puskesmas according to the results of Puskesmas performance or Puskesmas Performance Assessment (PKP) in 2019 amounted to $16 \%$ of the total patients treated, both outpatient or inpatient.

Based on research by Djaafar Nurseha (2013) Nurse Journal Vol. 8 No. 1 April 2013: 64-71 with the title Prevention and Control of Cross Infection in Dental Extraction Measures in the Dental Clinic of Kakaskasen Tomohon Health Center, In general the prevention and control of cross infection in the extraction of teeth both before, during, and after actions in the Dental Polyclinic of the Puskesmas Kakaskasen Tomohon not maximal..

Efforts to implement an accreditation policy that also implements PPI implementation have varied obstacles such as lack of commitment and support from stakeholders in the organization, limited financial resources to meet standards, limited certain human resources, lack of understanding of the concept of PPI implementation and how to apply the standards PPI into the organization, lack of followup from the authorities, lack of planning, culture and behavior of health service providers and time inefficiency. Therefore it is important to understand the implementation process not only about what works and what does not, but also understand how and why the implementation goes right or wrong, and test approaches to improve it. 
The Implementation Research Consolidation Framework (CFIR) is used to guide a systematic assessment of the implementation context at the multi-level to identify factors that can influence the implementation and effectiveness of an intervention. If used to evaluate the initial stage of implementing an intervention, the findings can help inform stakeholders about the area of intervention improvement and its implementation (Ministry of Health Republic of Indonesia, 2017: Puskesmas Management Training Module).

The process of implementing PPI at this Puskesmas will provide improved service quality if it is carried out comprehensively and systematically in accordance with established standards, thus the incidence of infection will go down, so it is necessary to study the policy of implementing PPI to services carried out by staff at Puskesmas Berbek Regency Nganjuk.

\section{METHODS}

The design of this study is to use a qualitative method using a standard case approach which is a type of qualitative research that looks closely at individual interpretations of their experiences. Data collection techniques used were Participant observational, independent interview, documentation and triangulation. Research instruments: Researchers as instruments (human instruments), notebooks, tape recorders, cameras. Data: qualitative descriptive, personal data documents, field notes, statements and actions of informants, documents etc. with a sample size of 10 informants who are officers in each service unit at the Puskesmas Brebek. Data validation using Triangulation Technique was done by 2 informants. In-depth interviews will be held from November 4, 2019 from December 17 to 2019.

RESULTS

Table 1. Characteristics of Respondents

\begin{tabular}{clcll}
\hline No & Code & Responden's Name & Age & Last Education \\
\hline 1 & P1 & Mr. S & 31 year & Nursing DIII \\
\hline 2 & P2 & Mr Mt & 56 year & Dentist \\
\hline 3 & P3 & Mrs. Hn & 50 year & Pharmacist assistant \\
\hline 4 & P4 & Mrs. Li & 43 year & Nursing DIII \\
\hline 5 & P5 & Mrs. La & 43 year & Nursing DIII \\
\hline 6 & P6 & Mrs. Lu & 48 year & Midwifery DIV \\
\hline 7 & P7 & Mrs. Y & 45 year & D III Health Analyst \\
\hline 8 & P8 & Mrs. A & 53 year & Midwifery DIV \\
\hline 9 & P9 & Mr. W & 34 year & Pharmacist \\
\hline 10 & P10 & Mrs. R & 39 year & Doctor \\
\hline 11 & Triangulation Informant 1 & Mr. E & 59 year & Head of Puskesmas \\
\hline 12 & Triangulation Informant 2 & Mrs. L & 49 year & Chairperson of PPI \\
\hline
\end{tabular}

Based on the table above, the age of the informants / Participants is between 31 to 56 years. The last formal education from the informant was educated DII through S1 Health. The status of being a Civil Servant and Contract Worker, the length of time he worked as a Health Worker at the Berbek Health Center was, on average, more than 10 years had worked at the Health Center. Of the 12 informants / participants who have been presented and conducted interviews, they are informants / participants who usually perform medical services, medical support services, at health centers that are always in contact with infectious conditions.

Triangulation informants / Participants were presented aged between 49 - 59 years. His last education was S1 Health, the triangulation was the Head of the Puskesmas and the Chair of the PPI (Infection Prevention and Control) in the Berbek Puskesmas.

\section{DISCUSSION}

Services for patients using PPE (masks, hand nests, service clothes, shoes and helmets) at the service center of the Berbek Puskesmas, Berbek District Nganjuk Regency are almost all carried out by officers.

Based on the interview results it was found that the service to patients using PPE (masks, hand nests, service clothes, shoes and helmets) conducted interviews with participants can be seen from the 
statement of almost all participants that the implementation of PPE use is adjusted to the actions carried out or based on SOPs that have been set in service.

Conducting services to patients must use PPE (masks, hand nests, service clothes, shoes and helmets) is a procedure that must be carried out by every service that aims to avoid nosocomial infections that occur in patients or that will befall the service providers so that patients and patients families feel safe and comfortable every time they receive treatment that is carried out by officers in the Berbek Puskesmas. The correct use of PPE is adapted to the conditions when providing services to patients, so that the procedure carried out really shows activities that will suppress the onset of transmission and nosocomial infections. Personal protective equipment (PPE) is a set of safety equipment used by workers to protect all or part of their bodies from the possibility of exposure to potential work environment hazards against work-related accidents and diseases. Personal protective equipment (PPE) is a set of tools used by workers to protect part or all of the body from being aware of potential hazards or work accidents. PPE does not perfectly protect the body, but can reduce the severity that may occur. This control should remain integrated and complement technical or administrative controls.

The use of PPE system is influenced by the accuracy of officers in carrying out procedures, and the application of procedures in a comprehensive manner by the implementation of services. from sterile and non-sterile gloves. Masks consist of disposable masks and cloth masks. Headgear. Protective and work clothes and protective shoes consist of cloth shoes and leather shoes.

\section{Not all clinical service officers carry out hand washing according to SOP in Berberk Puskesmas, Berbek District, Nganjuk Regency}

Based on the interview results it was found that to wash hands before and after the service, or action but there was one participant who did hand washing when the first patient and ended washing hands in the last patient, this participant was participant number P5, this participant reasoned not every patients wash their hands because there are many patients and patients do not need action so that the first patient is enough to wash hands first and the last patient to wash hands after service, this cannot be justified because it is not in accordance with SOP and can cause nosocomial infections both to the officer or to other patients .

Conducting services that always begin and end with hand washing is a procedure that must be carried out by each service provider that aims to avoid the transmission of disease from the patient officer or from other patient officers or his family. This is called a nosocomial infection, therefore increasing discipline in washing hands must be routinely carried out even monitoring should be done that is useful to avoid various types of transmission that are generated from unclean hands media that do not wash hands. Hand washing is the process of removing dirt and dust mechanically from the skin of both hands by using soap and water. The aim is to remove dirt and dust mechanically from the surface of the skin and temporarily reduce the number of microorganisms. Hand hygiene that does not meet the requirements also contributes to causing food-related diseases, such as salmonella bacterial infection and E. Coli infection. Washing hands with soap will make the bacteria escape from the hands Hand washing is one way to avoid food-borne diseases. The benefits of washing hands for 20 seconds are as follows: preventing the risk of contracting the disease, preventing contracting serious diseases such as hepatitis A, meningitis and others, reducing the risk of getting diarrhea and other digestive diseases by up to $59 \%$. If washing hands has become a habit that cannot be abandoned, a million deaths can be prevented every year. To keep the skin sterile from harmful germs that can infect, then you are obliged to wash your hands properly before and after doing service activities.

\section{Not all service places have a record of nosocomial infections in the Berbek Puskesmas, Berbek District, Nganjuk Regency}

Based on interviews, it was found that not all rooms have a nosocomial infection aid book, this is in the polyclinic room, dispensary room, they assume that they do not need a nosocomial infection book because they assume that nsocomial infection is only for patients who take action.

Ownership of nosocomial infection logbooks must be made to monitor and evaluate all activities related to nosocomial infections, so that conditions for nosocomial infections can be analyzed to report in the records of improving the quality of health centers. This book is not only for carrying out monitoring, but it is also used as a document that complements the Ministry of Health's regulation. 
Infection is the event of entry and multiplication of microorganisms in the body of the host that is able to cause illness. Nosocomial infection is an infection that is obtained by a person within $3 \times 24$ hours after they are admitted to the hospital. Nosocomial infection is caused by the provision of health services in a health care facility. The hospital is one of the most likely places of infection because it contains a high population of microorganisms with virulent types that may be resistant to antibiotics. To anticipate and record about nosocomial infections is a help book or a record of nosocomial infections.

\section{It was found that some of the clinical service personnel who carried out the injection were still disposing of needles with a closed lid}

Based on interviews, injection results were carried out by all participants except participants P3, $\mathrm{P} 7$ and $\mathrm{P} 9$ because the $\mathrm{P} 3$ profession was a pharmacist's assistant and $\mathrm{P} 9$ was a pharmacist and $\mathrm{P} 7$ was a laboratory analyst, for P7 discarding needles after the blood specimen was put into a reagent bottle.

Sharps medical waste is an object or device that has sharp edges / edges, prominent edges or parts that can cut or pierce the skin, such as hypodermic needles, intravenous equipment, pasteur pipettes, broken glass, scalpels. All of these sharp objects have the potential for danger and can cause injury through tears or punctures. Sharp objects that are wasted may be contaminated by blood, body fluids, microbiological materials and toxic cytotoxic or radioactive materials. Medical sharps have the potential for additional hazards that can cause infection or injury because they contain toxic or radioactive chemicals. The potential to transmit the disease will be very large if the sharp object was used for the treatment of infectious patients or infectious diseases. Sharps medical waste is solid material that has a sharp angle of less than 90 degrees, sides, edges or protruding parts that can cut, slice and pierce the skin. For example: syringes, intravenous equipment, pasteur pipettes, glass preparations or glass preparations, infusion sets, ampoules or drug vials, scalpels. In addition it includes wasted sharp objects that may be contaminated by blood, body fluids, microbiological substances, toxic or radioactive materials. Sharp objects are materials that can cause cuts, stab wounds, tears and injuries including needles, syringes, scapels and other types of daggers, knives, infusion equipment, saws, broken glass, and nails, both contaminated or not, sharp objects is a waste that is very dangerous and has the potential to transmit disease.

\section{PPI Constraints and Obstacles Officers are not compliant with SOPs made according to the agreement.}

Constraints and obstacles in implementing PPI, especially in implementing infection prevention and control that are not in accordance with SOP, can be caused by various factors including the standard factors that are set too tight, which means that the use of PPE standard must adjust to Permenkes Number 27 of 2017 concerning PPI. In addition, the standard standards as quality standards or indices that are available at the Puskesmas are still using two references, namely referrals from the Provincial Health Office that set PPI standards using PKP (Puskesmas Performance Assessment) indicators, while from the Ministry of Health the standards given are in accordance with Permenkes Number 27 in 2017 on PPI in which details explain the standard standards which are also partly not the same as the provincial PKP, this is what causes confusion in the management of Puskesmas in setting quality indicators or PPI quality standards.

In addition, health workers in the Berbek Puskesmas do not all understand the agreed SOPs, this is because the PPI team has not implemented and socialized the SOPs that have been passed so that compliance in implementing PPI cannot be consistent and maximum. This condition causes PPI program achievements to not reach the target.

These constraints and obstacles are also found in previous research studies including research by Djaafar Nurseha (2013) Nurse's health belief model is a description of nurses' behavior in implementing nosocomial infection prevention measures consisting of 4 domains: vulnerability, seriousness, benefits and resistance. The level of education shows the professionalism and performance of implementing nosocomial infection prevention measures, so the higher the level of education the higher the level of professionalism and performance. Vulnerability is one's view of susceptibility or susceptibility of a person to an illness (risk of becoming ill). A preventive measure for a disease will arise if someone has felt that he is vulnerable to the disease. Nosocomial infections can occur anywhere in the hospital. Hospital as a health facility that provides health services to the community, strives to be able to provide quality and professional services supported by competent human resources. Systematic, active and 
continuous observation of the emergence and spread of disease in the population and of conditions that cause an increased risk of disease spread, is an important part in the process of controlling infectious diseases. Control of nosocomial infections must be prioritized for sufferers and to break the chain of infection, prioritize nurses by changing behavior.

\section{CONCLUSION}

1. Policy on the Implementation of Infection Prevention and Control in Berbek Nganjuk District Health Center is implemented by the majority of participants.

2. Services carried out in the effort to prevent and control nosocomial infections by Nganjuk District Health Center staff can be prevented by managing Infection Prevention and Control.

3. Constraints and obstacles in the implementation of Prevention and Control of Infection in Ngekuk District Puskesmas Puskesmas still carried out by some respondents.

4. The role of health workers or staff in the policy of implementing Infection Prevention and Control in Ngekuk District Health Center is not able to be carried out by all puskesmas staff providing services.

\section{REFERENCE}

Dick AW, Perencevich EN, Pogorzelska-Maziarz M, Zwanziger J, Larson EL, Stone PW. (2015). A decade of investment in infection prevention: A cost-effectiveness analysis. American Journal Of Infection Control. 43(1):4-9.

Gunibala. 2015. Manajemen Kinerja. Jakarta: PT. Rajagrafindo Persada. Jakarta

Iwan Dwi Prahasto, dari Clinical epidemiologi dan biostatic unit MMR Fakultas Kedokteran UGM.

Komite Akreditasi Rumah Sakit (KARS). 2012 . Instrumen Akreditasi Rumah Sakit Standar Akreditasi Versi 2012. Jakarta

Lele Joyce dan Dail Field, (2010), "Participative Decision Making and Organizational Commitment Comparing Nigerian and American Employees, Cross Cultural Management",

Mulyaningsih.(2013). Peningkatan Kinerja Perawat dalam Penerapan MPKP dengan Supervisi oleh Kepala Ruang di RSJD Surakarta.Gaster. 10(1):57-70.

Mulyono M. Hadi dkk.(2012). Faktor Yang Berpengaruh Tehadap Kinerja Perawat di RS Tingkat III.16.06.01 Ambon. Jurnal AKK. 2 (1): 18- 26.

Mustikawati. 2011. Manajemen Sumber Daya Manusia 2nd ed. Jakarta:PT. Prenhallindo: Jakarta

Moorhead \& Griffin. 2013. Organizations Behaviour Structure Process. Chicago: Irwin Book Team. Chicago.

Peraturan Menteri Kesehatan Nomor 27 tahun 2017 tentang Pencegahan Infeksi

Sihotang, B.F. (2006). Pengaruh Motivasi Terhadap Produktivitas Kerja Perawat

WHO Patient Safety (2009), The Joint Commission's Universal Protocol for Preventing Wrong Site, Wrong Procedure, Wrong Person Surgery

Djaafar Nurseha (2013) Jurnal Ners Vol. 8 No. 1 April 2013: 64-71 dengan judul Pencegahan dan Pengendalian Infeksi Silang pada Tindakan Ekstraksi Gigi di Poli Gigi Puskesmas Kakaskasen Tomohon

Greiska Rotti (2014) dalam jurnal JST Kesehatan Januari 2014, Vol.4 No.1 : 69 - 77 (ISSN 2252-5416) dengan judul The Relation's of Management Functions of The Head's Nurse Toward Overcome Action and Infection Control at Public Hospital of Prof R.D Kandou Manado 